\title{
Obesity - a genetic disease of adipose tissue?
}

\author{
Peter Arner \\ Karolinska Institute, Department of Medicine, CME, M61, Huddinge Hospital, S-141 86 Huddinge, Stockholm, Sweden
}

\begin{abstract}
Although the rapid increase in the prevalence of obesity in many countries suggests that environmental factors (mainly overeating and physical inactivity) play the most important role in the development of overweight, it is very likely that genetic factors also contribute. It appears that one major gene in combination with one or several minor genes constitute the genetic components behind excess accumulation of body fat in most obese individuals. However, monogenic obesity has been described in a few families due to changes in leptin, leptin receptor, prohormone convertase, pro-opiomelanocortin or melanocortin-4 receptor. None of the monogenic variants is of great importance for common human obesity; the latter genes are unknown so far. Results from genomic scans suggest that major obesity genes are located on chromosomes 2 , 10,11 and 20. Studies of candidate genes indicate that the minor obesity genes control important functions of adipose tissue, and that structural variance in these genes may alter adipose tissue function in a way that promotes obesity. Such genes are $\beta_{2^{-}}$and $\beta_{3}$-adrenoceptors, hormonesensitive lipase, tumour necrosis factor alpha, uncoupling protein-1, low-density lipoprotein receptor, and peroxisome proliferator activator receptor gamma-2. Some of these genes may promote obesity by gene-gene interactions (for example $\beta_{3}$-adrenoceptors and uncoupling protein-1) or gene-environment interactions (for example $\beta_{2}$-adrenoceptors and physical activity). Some are important for obesity only among women (for example $\beta_{2^{-}}$and $\beta_{3^{-}}$ adrenoceptors, low-density lipoprotein receptor and tumour necrosis factor alpha). Few 'nonadipose' genes have so far shown a firm association to common human obesity, which could suggest that the important genes for the development of excess body fat also control adipose tissue function.
\end{abstract}

Fat cells: Body mass index: Lipolysis: Thermogenesis: Adipocyte differentiation

\section{Introduction}

The prevalence of obesity increases rapidly in most countries, reaching almost epidemic proportions in areas where there has been a recent change in habits towards a more westernized lifestyle. As discussed (Hill \& Peters, 1998) the environmental contribution to the obesity epidemic is apparent. Nevertheless, the strong genetic component of obesity is established in numerous studies on twins and relatives (Bouchard, 1993). A recent analysis of some of these studies suggests that as much as $50-70 \%$ of variation in body mass index is attributable to genetic difference (Allison et al. 1996). In this review the recent development in genetic research on human obesity is summarized, in particular focusing on the notion that several important obesity genes may be involved in the regulation of human adipose tissue function and might cause excess body fat by a direct interaction with the fat cell. For comprehensive overviews of earlier work in the field of human obesity genetics, see Bouchard (1993); Bouchard \& Pérusse, (1996); Perusse et al. (1996); Chagnon et al. (1998). In the interest of space, review articles rather than original papers are cited whenever possible. Studies only showing a lack of association between a particular gene and obesity have not been incorporated in this review.

\section{Evidence for a genetic cause of rare forms of obesity}

Using recent developments in DNA technology, most of the monogenic obesities in rodent models have been identified within a few years (Rosenbaum et al. 1997). Some rare forms of monogenic obesity in humans have also been described (Table 1). Families with juvenile-onset morbid obesity have been screened for mutations in the genes causing monogenic obesity in the mouse. So far, mutations in the human genes coding for leptin (Montague et al. 1997; Strobel et al. 1998), leptin receptor (Clément et al. 1998), 
Table 1. Monogenic forms of obesity

\begin{tabular}{lll}
\hline Human gene & \multicolumn{1}{c}{ Reference* $^{*}$} & Corresponding mouse model \\
\hline Leptin & Montague et al. 1997 & $\mathrm{ob} / \mathrm{ob}$ \\
Leptin receptor & Clément et al. 1998 & $\mathrm{db} / \mathrm{db}$ \\
Proopiomelanocortin & Krude et al. 1998 & Agouti \\
Prohormone convertase 1 & Jackson et al. 1997 & fat/fat \\
Melanocortin 4 receptor & Vaisse et al. 1998; Yeo et al. 1999 & Mc4r-deficient mice \\
\hline
\end{tabular}

* Relevant first published references.

pro-opiomelanocortin (Krude et al. 1998), prohormone convertase-1 (Jackson et al. 1997) and melanocortin-4 receptor (Vaisse et al. 1998; Yeo et al. 1999) have been described, all of which associate with juvenile-onset morbid obesity. The mechanisms responsible for excess fat accumulation in the rare forms of monogenic human obesity are not known. However, it is likely that they share features of the pathophysiology behind the equivalent genetic forms of obesity among rodents (Table 1) which have been discussed extensively (Chua \& Leibel, 1997). As mentioned, these mutations are rare and they can only explain obesity among a few families. Several of the genes have been screened for an association to obesity among large populations but no important associations have been found (Echwald et al. 1999; Norman et al. 1999; Pérusse et al. 1999).

\section{Number of genes involved in common forms of human obesity}

The genes of importance for common forms of human obesity remain to be identified. The results of segregation analysis of several different pedigree samples suggest that a major gene is in control of the fat mass (see Ginsburg et al. 1998). On the other hand, a number of chromosomes have been identified using a genome-wide scan approach in family studies; at least one major obesity gene is located in each of these genes (Table 2). Thus chromosome numbers 2 (Comuzzie et al. 1997; Rotimi et al. 1999), 10 (Häger et al. 1998), 11 (Norman et al. 1998) and 20 (Lembertas et al. 1997; Lee et al. 1999) appear to contain one or several genes which are in control of body weight. The quantitatively most important locus in each of these genes is partly identified, but we do not know yet exactly which genes and which mutation(s) in the genes associate with obesity. It is of interest to note that some candidate genes believed to be involved in the etiology of obesity are located near the chromosomal loci described in Table 2. This includes leptin and pro-opiomelanocortin on chromosome 2, as well as agoutisignalling protein, CEBPB (an adipocyte differentiation gene) and adenosine deaminase on chromosome 20.

Table 2. Location of major human obesity genes

\begin{tabular}{lll}
\hline Chromosome & \multicolumn{1}{c}{ Reference* $^{*}$ Locus } \\
\hline 2 & Comuzzie et al. 1997 & p21 \\
10 & Häger et al. 1998 & $5 \mathrm{cM}$ from p-terminal \\
11 & Norman et al. 1998 & q21-22 \\
20 & Lembertas et al. 1997 & q13 \\
\hline
\end{tabular}

\footnotetext{
${ }^{*}$ Relevant first published references.
}

It is evident from the discussion above that segregation analysis and genome-wide scanning give different answers to the question whether one or several genes are involved in the etiology of common forms of human obesity. It is thought that several genes (in combination with environmental factors) cause obesity in a certain individual (Comuzzie \& Allison, 1998). A schematic picture of gene-environment interactions is given in Fig. 1. One of these genes may be a major one and the others could be minor obesity genes. The particular major and minor obesity genes may differ between families or ethnic groups. In the rest of this paper I discuss the relative importance of genes with a known function for human obesity. Through the socalled candidate gene approach, a number of polymorphisms in different genes have recently been found to be linked to human obesity. It is apparent that all of these are in control of major functions of adipose tissue.

\section{$\beta_{3}$-adrenergic receptor}

In 1995 it was discovered in three independent populations that a coding mutation in the $\beta_{3}$-adrenergic receptor (Trp64Arg) associated with obesity and certain features of the so-called metabolic (insulin resistance) syndrome (Strosberg, 1997a; Arner \& Hoffstedt, 1999). This polymorphism has given rise to enormous interest and almost 100 articles on the mutation have been published so far according to Medline. About half of the obesity studies show an association to overweight whereas the other half fail to demonstrate a relationship with obesity. Even metaanalyses show divergent results as regarding the link of Trp64Arg to body weight and obesity (Allison et al. 1998;

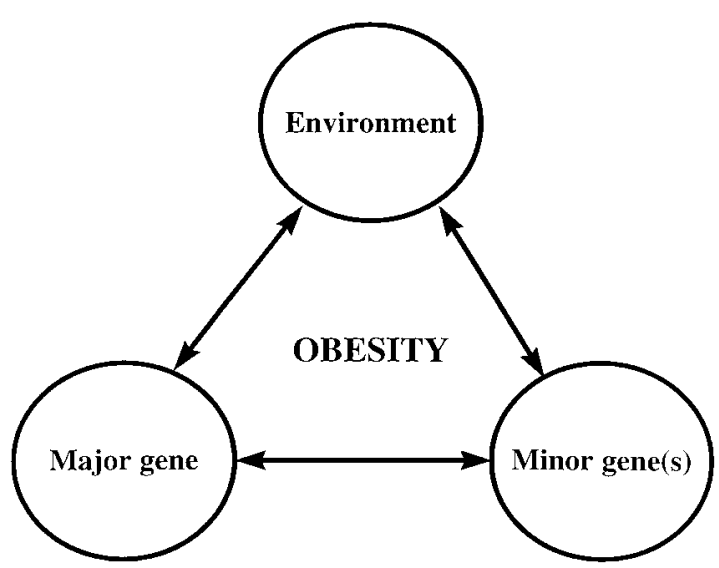

Fig. 1. Gene-environment interactions leading to obesity. 
Fujisawa et al. 1998). Although the reasons for the discrepant findings are not yet known, it is quite possible that the $\beta_{3}$-adrenoceptor is an important obesity gene.

The $\beta_{3}$-adrenoceptor is above all expressed and functional in white and brown fat cells (Lowell \& Fliers, 1997; Strosberg, 1997b). Although the brown adipose tissue mass is small in adult humans, the thermogenic effect in brown human fat cells can be activated both in vivo and in vitro by $\beta_{3}$-adrenergic agonists. Furthermore, $\beta_{3}$-receptors can stimulate lipolysis in white human adipose tissue although the receptor is less efficient in this respect in comparison with the co-existing $\beta_{1}$ and $\beta_{2}$ subtypes. Recent studies have shown that the Trp64Arg substitution in the $\beta_{3}$-adrenoceptor molecule markedly impairs the receptor function in human fat cells (Hoffstedt et al. 1999b; Umekawa et al. 1999) and decreases resting metabolic rate (Sipiläinen et al. 1997).

When all available information is considered together, it is possible that the adipocyte $\beta_{3}$-adrenoceptor is an obesity gene. The Trp64Arg mutation impairs receptor function and is associated with decreased thermogenesis. This may explain its association with obesity in several populations.

\section{$\beta_{2}$-adrenergic receptor}

The $\beta_{2}$-adrenoceptor plays several roles in the regulation of energy homeostasis, such as stimulation of glycogen breakdown and stimulation of lipid mobilization. It co-exists with $\beta_{1}$-and $\beta_{3}$-adrenoceptors in human white adipose tissue (see Carpene et al. 1998; Large \& Arner, 1998 for thorough reviews on its normal and pathophysiological function). The $\beta_{2}$-adrenoceptor is the dominating lipolytic adrenoceptor subtype under normal conditions and is downregulated in subcutaneous adipose tissue of obese subjects. The latter is an important underlying mechanism for the frequently observed lipolytic catecholamine resistance in human obesity.

Several coding mutations in the $\beta_{2}$-adrenoceptor gene are described that markedly impair receptor function in transfected cell lines (Büscher et al. 1999). At least one of these polymorphisms (Arg16Gly) associates with altered receptor function in human white fat cells (Large et al. 1997). Another $\beta_{2}$-receptor polymorphism, Gln27Glu, was strongly associated with obesity among Swedes (Large et al. 1997). It was confirmed that this polymorphism is linked to obesity in Japanese subjects (Ishiyama-Shigemoto et al. 1999; Mori et al. 1999). On the other hand, it is not associated with early onset obesity in Danes (Echwald et al. 1998). Gene-environment interactions for the Gln27Glu polymorphism are described (Meirhaeghe et al. 1999). An interaction between this polymorphism and body mass index is observed in sedentary but not in physically active subjects.

It could be speculated that the Gln27Glu polymorphism influences body fat accumulation (maybe in combination with physical inactivity) by changing the lipolytic response of adipose tissue to catecholamines, which are the major lipolysis-stimulating hormones in man. Bearing in mind the broad action of $\beta_{2}$-adrenoceptors, there are a number of other possibilities by which this receptor may promote obesity.

\section{Hormone-sensitive lipase}

Another important lipolysis-regulating protein is hormonesensitive lipase (Langin et al. 1996). Hormone-sensitive lipase is the final rate-limiting step for triglyceride breakdown in fat cells during lipolysis. It is stimulated by catecholamines and inhibited by insulin. As well as in adipose tissue, the enzyme is also functionally expressed in skeletal muscle and testis. The physiological importance in the latter two organs is not well understood. A number of studies have demonstrated decreased ability of catecholamines to stimulate lipolysis in subcutaneous adipose tissue (Large \& Arner, 1998). It was recently shown that this lipolysis defect could be explained in part by a decreased expression of hormone-sensitive lipase in fat cells (Large et al. 1999). The same type of lipolysis defect in hormonesensitive lipase also is found in non-obese subjects with heredity for obesity (Hellström et al. 1996).

Association between the hormone-sensitive lipase gene and obesity has been presented in two studies. A non-coding dinucleotide repeat was shown to associate with obesity in a French population (Magré et al. 1998). Genetic variability, detected by restriction fragment length polymorphism, associated with abdominal obesity in a Scandinavian population (Klannemark et al. 1998). It is not known if structural variants in hormone sensitive lipase gene are linked to altered enzyme function. It is possible that the polymorphisms only reflect more important genetic variance on chromosome 19 near the hormone-sensitive lipase locus, although no such evidence was found in a linkage study on French sib-pairs (Clément et al. 1999). When genetic and functional data are combined it is tempting to speculate that gene mutations directly or indirectly impair hormonesensitive lipase so that lipolysis in fat cells is decreased which, in turn, may promote obesity.

\section{Uncoupling proteins}

Uncoupling proteins belong to a family of proteins which can uncouple ATP production from mitochondrial respiration, thereby dissipating energy as heat and affecting energy expenditure (Schrauwen et al. 1999). Three different proteins are discovered. The first, UCP-1, is exclusively expressed in brown adipose tissue where it regulates the combustion of fatty acids (Cannon et al. 1998). Brown adipose tissue is present in considerable amounts in human newborns and plays an important role for thermogenesis in the intra-uterine and early phase of extra-uterine life. In adults, little brown adipose tissue is present but brown fat cells are found in several human tissues (Krief et al. 1993), and decreased gene expression of UCP-1 is detected in white adipose tissue of obese as compared to lean adult subjects (Oberkofler et al. 1997). It is possible to activate UCP-1 in human adipose tissue by $\beta_{3}$-adrenergic agonists through stimulation in vivo or in vitro. UCP-2 is expressed in several tissues (including adipose tissue) whereas UCP-3 is predominantly expressed in skeletal muscle. Also, the tissue expression of mRNA for both UCP-2 and UCP-3 is influenced by the obese state in man.

Polymorphisms in the genes for UCP-2 and UCP-3 show some association to resting metabolic rate, but published 
work suggests that none of these genes is likely to play an important role in human obesity (Otabe et al. 1999; Ricquier, 1999; Warden, 1999). On the other hand, a polymorphism (A to $\mathrm{G}$ ) at position -3826 in the $5^{\prime}$ flanking region of the UCP-1 gene influences weight loss and weight gain in obese subjects from France or Quebec (CassardDoulcier et al. 1996; Fumeron et al. 1996; Oppert et al. 1999). Interestingly, there are also important interactions between the genes for UCP- 1 and $\beta_{3}$-adrenergic receptor. Thus synergistic effects of $\mathrm{A}(-3826) \mathrm{G}$ in UCP-1 and Trp64Arg in $\beta_{3}$-adrenoceptor on basal metabolic rate in obese Finns (Valve et al. 1998) and on weight gain or weight loss in obese French or Finnish subjects (Clément $e t$ al. 1996; Fogelholm et al. 1998) are reported. It should be noted, though, that no relationship between the described UCP-1 polymorphism and obesity variables was found in Swedish subjects (Cagnon et al. 1998). Based on the findings discussed above it is possible that UCP-1 is an obesity gene in humans. Mutations in or near this gene could influence metabolic rate and thereby cause changes in body fat stores. Such an effect on thermogenesis may be of particular importance when genetic variance in UCP-1 and $\beta_{3}$-adrenoceptor genes co-exists.

\section{Peroxisome proliferator-activated receptor gamma-2 $(P P A R \gamma$-2)}

Peroxisome profilerator-activated receptors, especially PPAR $\gamma-2$, are key regulators of adipocyte differentiation and energy storage (Schoonjans et al. 1997). The expression of mRNA coding for PPAR $\gamma$ - 2 is increased in adipose tissue of obese subjects. Two coding mutations, which are functional, have been described in PPAR $\gamma-2$. A Pro115Gln mutation accelerates the differentiation of adipocytes and is associated with morbid obesity in Germans (Ristow et al. 1998). A Pro12Ala substitution associated with decreased receptor activity and lower body mass index in Finns (Deeb et al. 1998), and in lean but not in obese Danes (Ek et al. 1999).

The PPAR $\gamma$-2 mutations are very rare. So far only a handful of subjects have been described who are homozygous for either of the two mutations; heterozygotes seem to have a normal phenotype (Mori et al. 1998; Ek et al. 1999). More research, including investigations of additional and large populations, is needed to ascertain whether PPAR $\gamma-2$ is an important obesity gene. It could be speculated, though, that genetic variance in PPAR $\gamma-2$ affects adipocyte differentiation and subsequently alters the normal development of the fat mass.

\section{Tumor necrosis factor alpha $(T N F-\alpha)$}

The cytokine TNF- $\alpha$ modulates the expression of several genes in adipose tissue and is implicated in the development of obesity (Hotamisligil \& Spiegelman, 1994). The most important TNF- $\alpha$ effect for obesity is the ability to modulate insulin sensitivity, mainly by inhibiting insulin signalling in fat cells (Hotamisligil, 1999). TNF- $\alpha$ has also other actions in adipose tissue that could play a role in obesity: it can induce apoptosis of fat cells (Prins et al. 1997) and stimulate lipolysis; the latter is achieved by decreasing the expression of the lipolysis-inhibiting $\mathrm{G}_{\mathrm{i}}$ protein in adipocytes (Gasic et al. 1999).
Genetic studies using sibling-pair analysis demonstrated linkage between a marker near the TNF- $\alpha$ and body fat content in Pima Indians (Norman et al. 1995). A polymorphism upstream of the transcription start site of TNF- $\alpha$ ( $\mathrm{G}$ to $\mathrm{A}$ at position -308 ) associated with obesity in several European populations (Férnandez-Real et al. 1997; Herrmann et al. 1998). It was recently found in Swedes that the latter polymorphism influences body fat content only in homozygous subjects (Hoffstedt et al. 2000). A/A (-308) subjects had excessive fat accumulation in comparison to heterozygous and $G / G(-308)$ subjects. The latter may suggest that TNF- $\alpha$ is a recessive obesity gene. It is unclear how the 308 polymorphism alters the function of TNF- $\alpha$, although in vitro studies have documented that this genetic variance influences the transcription of the TNF- $\alpha$ gene in lymphocytes (Wilson et al. 1997).

TNF- $\alpha$ is widely expressed and has many divergent actions which could influence storage of body fat. However, it is possible that structural variance in the gene alters the expression of TNF- $\alpha$ in fat cells so that lipolysis, insulin sensitivity and apoptosis in adipose tissue are changed in a way which causes excess body fat accumulation.

\section{Low-density lipoprotein receptor (LDL-R)}

LDL-R is a widely expressed receptor which has multiple roles in lipid metabolism (Willnow, 1999). Of particular interest for adipose tissue is that it mediates fat cell uptake of lipids from remnant lipoproteins (Descamps et al. 1993). Several studies have shown that a polymorphic marker near the locus for LDL-R has relatively strong linkage to obesity (see Pérusse et al. 1999 for references). The exact nature of this polymorphism remains to be established. Although several obesity-promoting mechanisms not directly involving adipose tissue are possible for LDL-R, it could be speculated that structural variance in the corresponding gene leads to increased lipid uptake by fat cells so that excess storage of fat in adipose tissue is developed.

\section{Other genes}

Single nucleotide substitution and small base deletions and insertions are the most common forms of DNA polymorphism and disease-causing mutations in the human genome. Using recent advances in DNA sequencing and computerized bioinformation, it is possible to rapidly screen several mutations simultaneously in large population samples $(\mathrm{Gu}$ et al. 1998; Wacey \& Tuddenham, 1998). Using similar or simpler approaches, a number of polymorphisms in several genes other than those mentioned above have been investigated regarding an association with obesity (see Pérusse et al. 1999 for references). Most of these genes have no known important function in adipose tissue. So far either no or a weak association between these 'non-adipose tissue' genes and obesity has been demonstrated; usually only a single report for each of the genes is published.

\section{Gender and obesity genes}

It is well known that body fat distribution usually differs between men and women. Men often have upper-body 
obesity, whereas peripheral obesity is the most common form among women. Family studies strongly suggest that body fat distribution, in particular visceral fat level, is governed by genetic factors (Katzmarzyk et al. 1999). Several of the polymorphisms discussed in this review have a different impact on body fat in men than in women.

Many studies suggest that the Trp64Arg polymorphism in the $\beta_{3}$-adrenoceptor is associated with obesity only in women (Arner \& Hoffstedt, 1999). The Gln27Glu polymorphism in the $\beta_{2}$-adrenoceptor is linked to obesity in women but not in men in a Swedish population (Hellström et al. 1999). The A/G(-3081) polymorphism in the TNF- $\alpha$ gene associated with excess body fat in women but not in men in a study on Swedes (Hoffstedt et al. 2000). Association of an LDL-R microsatellite variant with obesity was found in females, but not in males (Rutherford et al. 1997). These data indicate that men and women have different obesity genes. Clearly more studies are needed on the interactions between gender, genes and obesity.

\section{Conclusions}

In the past few years knowledge of the genetics behind obesity has increased dramatically. Most of the genes causing monogenic obesity in the mouse have been discovered, and the mechanisms behind their control of body fat accumulation have been elucidated in part. Some of these genes do cause excess fat accumulation in a few human subjects. However, genetic control of common forms of human obesity is poorly understood, although family studies suggest that major genes in the control of body fat stores are located in chromosomes 2, 10, 11 and 20. Through the candidate gene approach, several genes have been identified which might be considered as minor obesity genes because polymorphism in these genes is associated with obesity in some but not all subjects. It is apparent that

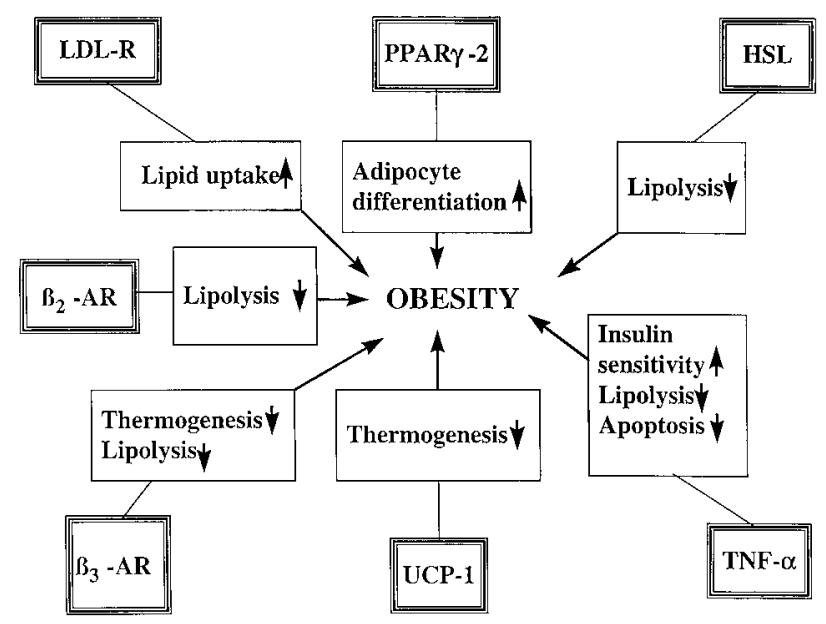

Fig. 2. A tentative model showing how changes in the structure of genes controlling important actions in human adipose tissue may cause obesity by altering fat cell function. $\beta_{2}-\mathrm{AR}=\beta_{2}$-adrenoceptor; $\beta_{3}-\mathrm{AR}=\beta_{3}$-adrenoceptor; $\mathrm{HSL}=$ hormone-sensitive lipase; PPAR $\gamma$-2=peroxisome profilerator-activated receptor gamma-2; UCP-1 = uncoupling protein-1; TNF- $\alpha=$ tumour necrosis factor alpha; $L D L-R=$ low-density lipoprotein receptor. most of the minor candidate genes control important functions in adipose tissue. Therefore genetic variations in the latter genes may alter adipose tissue function in a way that promotes the development of obesity (Fig. 2). Thus changes in the genes encoding for $\beta_{2}$-adrenoceptors, $\beta_{3}$-adrenoceptors, hormone-sensitive lipase and TNF- $\alpha$ may inhibit lipolysis. TNF- $\alpha$ polymorphism could also improve insulin sensitivity and reduce adipocyte apoptosis. A genetic variation in PPAR $\gamma-2$ may increase adipocyte differentiation. Genetic variation in UCP-1 (and $\beta_{3}$-adrenoceptors) could decrease thermogenesis. LDL-R polymorphisms might increase lipid storage in adipose tissue. All these variations in the genetic code could promote excess fat accumulation. Some genes may interact in the development of an obese phenotype, such as UCP-1 and $\beta_{3}$-receptor. Gene-environment interactions may also play a pathophysiological role in the cause of obesity, for example between physical activity and the $\beta_{2}$ adrenoceptor gene. Finally, there might be different obesity genes (at least minor ones) among women and men: for example, the genes encoding for $\beta_{2}$-adrenoceptors, $\beta_{3^{-}}$ adrenoceptors, TNF- $\alpha$ and LDL-R may be more important for obesity development in women than in men. I do want to emphasize that genes which are widely expressed such as the $\beta_{2}$-adrenoceptor, TNF- $\alpha$ and LDL-R may cause obesity in a number of ways not directly involving adipose tissue. On the other hand, it is difficult to understand how the genes for hormone sensitive lipase, $\beta_{3}$-adrenoceptor, UCP-1 and PPAR $\gamma-2$ could promote obesity without directly involving the fat cells. It is therefore an attractive speculation that structural variability in genes controlling the function of adipose tissue is important for common forms of human obesity.

\section{Acknowledgement}

This study was supported by Medicus Bromma, Ltd.

\section{References}

Allison DB, Kaprio J, Korkeila M, Koskenvuo M, Neale MC \& Kayakawa K (1996) The heritability of body mass index among an international sample of monozygotic twins reared apart. International Journal of Obesity 20, 501-506.

Allison DB, Heo M, Faith MS \& Pietrobelli A (1998) Metaanalysis of the associaton of the Trp64Arg polymorphism in the $\beta_{3}$-adrenergic receptor with body mass index. International Journal of Obesity 22, 559-566.

Arner P \& Hoffstedt F (1999) Adrenoceptor genes in human obesity. Journal of Internal Medicine 6, 667-672.

Bouchard C (1993) Genes and body fat. American Journal of Human Biology 5, 425-432.

Bouchard C \& Pérusse L (1996) Current status of the human obesity gene map. Obesity Research 4, 81-90.

Büscher R, Herrmann V \& Insel PA (1999) Human adrenoceptor polymorphisms: evolving recognition of clinical importance. Trends in Pharmacological Sciences 20, 94-99.

Cagnon J, Lago F, Chagnon YC, Pérusse L, Näslund I, Lissner L, Sjöström L \& Bouchard C (1998) DNA polymorphism in the uncoupling protein 1 (UCP1) gene has no effect on obesity related phenotypes in the Swedish obese subjects cohorts. International Journal of Obesity 22, 500-505.

Cannon B, Houstek J \& Nedergaard J (1998) Brown adipose tissue. 
More than an effector of thermogenesis? Annals of New York Academy of Science 856, 171-187.

Carpene C, Bousquet-Melou A, Galitzky J, Berlan M \& Lafontan M (1998) Lipolytic effects of beta $1^{-}$, beta $2^{-}$and beta $3^{-}$adrenergic agonists in white adipose tissue of mammals. Annals of New York Academy of Science 839, 186-189.

Cassard-Doulcier AM, Bouillaud F, Chagnon M, Gelly C, Dionne FT, Oppert JM, Bouchard C, Chagnon Y \& Ricquier D (1996) The Bcll polymorphism of the human uncoupling protein (UCP) gene is due to a point mutation in the $5^{\prime}$ flanking region. International Journal of Obesity 3, 278-279.

Chagnon YC, Pérusse L \& Bouchard C (1998) The human obesity gene map: the 1997 update. Obesity Research 6, 76-92.

Chua S \& Leibel RL (1997) Obesity genes. Molecular and metabolic mechanisms. Diabetes Reviews 5, 2-7.

Clément K, Ruiz J, Cassard-Doulcier AM, Bouillaud R, Ricquier D, Basdevant A, Guy-Grand B \& Froguel P (1996) Additive effect of A G (-3826) variant of the uncoupling protein gene and the Trp64Arg mutation of the beta3-adrenergic gene on weight gain in morbid obesity. International Journal of Obesity 12, $1062-1066$.

Clément K, Vaiesse C, Lahlou N, Cabrol S, Pelbux V, Cassuto D, Gourmelen M, Dina C, Chambay J, Lacorte JM, Basdevant A, Bougneres P, Lebouc Y, Frougel P \& Guy-Grand B (1998) A mutation in the human leptin receptor gene causes obesity and pituitary dysfunction. Nature 6674, 398-401.

Clément K, Dina C, Basdevant A, Chastang N, Pelloux V, Lahlou N, Berlan M, Langin D, Guy-Grand B \& Frougel P (1999) A sibpair analysis study of 15 candidate genes in French families with morbid obesity. Diabetes 48, 398-402.

Comuzzie AG \& Allison DB (1998) The search for human obesity genes. Science 280, 1374-1377.

Comuzzie AG, Hixson JE, Almasy L, Mitchell BD, Mahaney MC, Dyer TD, Stern MP, MacCluer JW \& Blangero J (1997) A major quantitative trait locus determining serum leptin levels and fat mass is located on human chromosome 2. Nature Genetics $\mathbf{1 5}$, 273-276.

Deeb SS, Fajas L, Nemoto M, Pihlajamäki J, Mykkänen L, Kuusisto J, Laakso M, Fujimoto W \& Auwerx J (1998) A Pro12Ala substitution in PPAR $\gamma-2$ with decreased receptor activity, lower body mass index and improved insulin sensitivity. Nature Genetics 20, 284-287.

Descamps O, Bilheimer D, Herz J (1993) Insulin stimulates receptor-mediated uptake of apoE-enriched lipoproteins and activated alpha 2-macroglobulin in adipocytes. Journal of Biological Chemistry 2, 974-981.

Echwald SM, Sörensen TIA, Tybjaerg-Hansen A, Andersen T \& Pedersen O (1998) Gln 27Glu variant of the human $\beta_{2}$-adrenoceptor gene is not associated with early-onset obesity in Danish men. Diabetes 47, 1657-1658.

Echwald SM, Sörensen TIA, Andersen T, Tubjaerg-Hansen A, Clausen JO \& Pedersen O (1999) Mutational analysis of the proopiomelanocortin gene in Caucasians with early onset obesity. International Journal of Obesity 23, 293-298.

Ek J, Urhammer SA, Sörensen TIA, Andersen T, Auwerz J \& Pedersen O (1999) Homozygosity of the Pro12Ala variant of the peroxisome proliferation-activated receptor- $\gamma$-2 (PPAR $\gamma-2)$ : divergent modulating effects on body mass index in obese and lean Caucasian men. Diabetologia 42, 892-895.

Férnandez-Real J M, Gutierrez C, Ricart W, Casamitjana R, Fernández-Castaner M, Vendrell J, Richart C \& Soler J (1997) The TNF- $\alpha$ gene NcoI polymorphism influences the relationship among insulin resistance, percent body fat and increased serum leptin levels. Diabetes 46, 1468-1472.

Fogelholm M, Valve R, Kukkonne-Harjula K, Nenonen A, Hakkarainen V, Laakso M \& Uusitupa M (1998) Additive effects of the mutations in the $\beta_{3}$-adrenergic receptor and uncoupling protein-1 genes on weight loss and weight maintenance in Finnish women. Journal of Clinical Endocrinology Metabolism 83, 4246-4250.

Fujisawa T, Ikegami H, Kwaguchi Y \& Ogihara T (1998) Meta-analysis of the association of Trp64Arg polymorphism of $\beta_{3}$-adrenergic receptor gene with body mass index. Journal of Clinical Endocrinology and Metabolism 83, 2441-2444.

Fumeron F, Durack-Bown I, Betoulle D, Cassard-Doulcier AM, Tuzet S, Bouillaud F, Melchior JC, Ricquier D \& Apfelbaum M (1996) Polymorphisms of uncoupling protein (UCP) and beta3adrenoceptor genes in obese people submitted to a low calorie diet. International Journal of Obesity 12, 1051-1054.

Gasic S, Tian B \& Green A (1999) Tumor necrosis factor-alpha stimulates lipolysis in adipocytes by decreased $G_{i}$ protein concentrations. Journal of Biological Chemistry 10, 67706775.

Ginsburg E, Livshits G, Yakovenko K \& Kobyliansky E (1998) Major gene control of human body height, weight and BMI in five ethnically different populations. Annals of Human Genetics 62, 307-322.

Gu Z, Hillier L \& Kowk P-Y (1998) Single nucleotide polymorphism hunting in cyberspace. Human Mutation 12, 221-225.

Häger J, Dina C, Francke S, Dubouis S, Houari M, Vatin V, Vaillant E, Lorentz N, Basdevant A, Clement K, Guy-Grand B \& Frougel P (1998) A genome-wide scan for human obesity genes reveals a major susceptibility locus on chromosome 10 . Nature Genetics 20, 304-308.

Hellström L, Langin D, Reynisdottir S, Dauzats M \& Arner P (1996) Adipocyte lipolysis in normal weight subjects with obesity among first-degree relatives. Diabetologia 8, 921-928.

Hellström L, Large V, Reynisdottir S, Wahrenberg H \& Arner P (1999) The different effects of Gln27Glu beta ${ }_{2}$-adrenoceptor gene polymorphism on obesity in males and females. Journal of Internal Medicine 3, 253-259.

Herrmann S M, Ricard S, Nicaud V, Mallet C, Arveilert D, Evans A, Ruidavets J B, Luc G, Bara L, Parra H J, Poirier O \& Cambien F (1998) Polymorphisms of the tumour necrosis factor- $\alpha$ gene, coronary heart disease and obesity. European Journal of Clinical Investigation 28, 59-66.

Hill JO \& Peters JC (1998) Environmental contributions to the obesity epidemic. Science 280, 1371-1374.

Hoffstedt J, Eriksson P, Hellström L, Rössner S, Rydén M \& Arner $\mathrm{P}$ (2000) Excessive fat accumulation is associated with the TNF$\alpha-308 \mathrm{G} / \mathrm{A}$ promoter polymorphism in women but not in men. Diabetologia 43, 117-120.

Hoffstedt J, Poirier O, Thörne A, Lönnqvist F, Herrmann SM, Cambien F \& Arner P (1999b) Polymorphism of the human $\beta_{3^{-}}$ adrenoceptor gene forms a well-conserved haplotype that is associated with moderate obesity and altered receptor function. Diabetes 48, 203-205.

Hotamisligil GS (1999) Mechanisms of TNF-alpha-induced insulin resistance. Experimental Clinical Endocrinology and Diabetes 107, 119-125.

Hotamisligil GS \& Spiegelman BM (1994) Tumor necrosis factor alpha: a key component of the obesity-diabetes link. Diabetes 43, 1271-1278.

Ishiyama-Shigemoto S, Yamada K, Yuan X, Ichikawa E \& Nonaka $\mathrm{K}$ (1999) Association of polymorphisms in the $\beta_{2}$-adrenergic receptor gene with obesity, hypertriglyceridaemia, and diabetes mellitus. Diabetologia 42, 98-101.

Jackson RS, Creemers JW, Ohagi S, Raffin-Sanson ML, Sanders L, Montague CT, Hutton JC \& O'Rahilly S (1997) Obesity and impaired prohormone processing associated with mutations in the human prohormone convertase 1 gene. Nature Genetics $\mathbf{3}$, 303-306.

Katzmarzyk P, Pérusse L \& Bouchard C (1999) Genetics of 
abdominal visceral fat levels. American Journal of Human Biology 11, 225-235.

Klannemark M, Orho M, Langin D, Laurell H, Holm C, Reynisdottir S, Arner P \& Groop L (1998) The putative role of the hormone-sensitive lipase gene in the pathogenesis in type II diabetes mellitus and abdominal obesity. Diabetologia 41, $1516-1522$.

Krief S, Lönnqvist F, Raimbault S, Baude B, van Spronsen A, Arner P, Strosberg AD, Ricquier D \& Emorine LJ (1993) Tissue

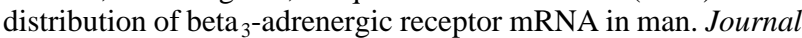
of Clinical Investigation 91, 344-349.

Krude H, Biebergmann H, Luck W, Horn R, Brabant C \& Gruters A (1998) Severe early-onset obesity, adrenal insufficiency and red hair pigmentation caused by POMC mutations in humans. Nature Genetics 2, 155-157.

Langin D, Holm C \& Lafontan M (1996) Adipocyte hormone sensitive lipase: a major regulator of lipid metabolism. Proceedings of the Nutrition Society 55, 93-109.

Large V \& Arner P (1998) Regulation of lipolysis in humans. Pathophysiological modulation in obesity, diabetes and hyperlipidaemia. Diabetes and Metabolism 5, 409-418.

Large V, Hellström L, Reynisdottir S, Lönnqvist F, Eriksson P, Lannfelt L \& Arner P (1997) Human beta-2 adrenoceptor gene polymorphisms are highly frequent in obesity and associate with altered adipocyte beta-2 adrenoceptor function. Journal of Clinical Investigation 100, 3005-3013.

Large V, Reynisdottir S, Langin D, Fredby K, Klannemark M, Holm C \& Arner P (1999) Decreased expression and function of adipocyte hormone-sensitive lipase in subcutaneous fat cells of obese subjects. Journal of Lipid Research, 40, 2059-2065.

Lee JH, Reed DR, Li W-D, Xu W, Joo E-J, Kilker RL, Nanthakumar E, North M, Sakul H, Bell C \& Price RA (1999) Genome scan for human obesity and linkage to markers in $20 \mathrm{q} 13$. American Journal of Human Genetics 64, 196-209.

Lembertas AV, Pérusse L, Chagnon YC, Fisler JS, Warden CH, Purcell-Huynh DA, Dionne FT, Gagnon J, Nadeua A, Lusis AJ \& Bouchard C (1997) Identification of an obesity quantitative trait locus on mouse chromosome 2 and evidence of linkage to body fat and insulin on the human homologous region 20q. Journal of Clinical Investigation 100, 1240-1247.

Lowell BB \& Fliers JS (1997) Brown adipose tissue, beta ${ }_{3}$ adrenergic receptor and obesity. Annual Review of Medicine 48, 307-316.

Magré J, Laurell H, Fizames C, Antoine PJ, Dib C, Vigouroux C, Bourut C, Capeau J, Weissenbach J \& Langin D (1998) Genetic mapping, identification of a new dinucleotide repeat, and association with obesity and NIDDM. Diabetes 47, 284286.

Meirhaeghe A, Helbecque N, Cottel D \& Amouyel P (1999) $\beta_{2^{-}}$ adrenoceptor gene polymorphism, body weight and physical activity. Lancet 353, 896.

Montague CT, Faroogi IS, Whitehead JP, Soos MA, Rau H, Wareham NJ, Sewter CP, Digby JE, Mohammed SN, Hurst JA, Cheetham CH, Earley AR, Barnett AH, Prins JB \& O'Rahilly S (1997) Congenital leptin deficiency is associated with severe early-onset obesity in humans. Nature 387, 903908.

Mori Y, Kim-Motoyama H, Katakura T, Yasuda K, Kadowaki H, Beamer BA, Shuldiner AR, Akanuma Y, Yazaki Y \& Kadowaki T (1998) Effect of the Pro12Ala variant of the human peroxisome proliferator-activated receptor $\gamma$-2 gene on adiposity, fat distribution and insulin sensitivity in Japanese men. Biochemical and Biophysical Research Communications 251, 195-198.

Mori Y, Kim-Motoyama H, Ito Y, Katakura T, Yasuda K, Ishiyama-Shigemoto S, Yamada K, Akanuma Y, Ohashi Y, Kimura S, Yazaki Y \& Kadowaki Y (1999) The Gln27Glu $\beta_{2-}$ adrenergic receptor variant is associated with obesity due to subcutaneous fat accumulation in Japanese men. Biochemical and Biophysical Research Communciations 258, 138-140.

Norman RA, Bogardus C \& Ravussin E (1995) Linkage between obesity and a marker near the tum or necrosis factor-alpha locus in Pima Indians. Journal of Clinical Investigation 96, 158-162.

Norman RA, Tataranni PA, Pratley R, Thompson DB, Hanson RL, Prochazka M, Baier L, Ehm MG, Sakul H, Foroud T, Garvey WT, Burns D, Knowler WC, Bennett PH, Bogardus C \& Ravussin E (1998) Autosomal genomic scan for loci linked to obesity and energy metabolism in Pima Indians. American Journal of Human Genetics 62, 659-668.

Norman RA, Permana P, Tanizawa Y \& Ravussin E (1999) Absence of genetic variation in some obesity candidate genes (GLP1R, ASIP, MC4R, MC5R) among Pima Indians. International Journal of Obesity 23, 163-165.

Oberkofler H, Dallinger G, Liu YM, Hell E, Krempler F \& Patcsh W (1997) Uncoupling protein gene: quantification of expression levels in adipose tissue of obese and non-obese humans. Journal of Lipid Research 10, 2125-2133.

Oppert JM, Vohlm C, Chagnon M, Dionne F, Cassard-Doulcier AM, Ricquier D, Perusse L \& Bouchard C (1999) DNA polymorphism in the uncoupling protein (UCP) gene and human body fat. International Journal of Obesity 8, 526-531.

Otabe S, Clement K, Dubois S, Lepretre F, Pelloux V, Leibel R, Chung W, Boutin P, Guy-Grand B, Frougel P \& Vasseur F (1999) Mutation screening and association studies of the human uncoupling protein 3 gene in normoglycemic and diabetic morbidyly obese patients. Diabetes 48, 206-208.

Pérusse L, Chagnon YC, Dionne FT \& Bouchard C (1996) The human obesity gene map: the 1996 update. Obesity Research $\mathbf{5}$, 49-51.

Pérusse L, Chagnon YC, Weisnagel J \& Bouchard C (1999) The human obesity gene map: the 1998 update. Obesity Research 7 , 111-129.

Prins JB, Nielser CU, Winterford CM, Bright NA, Siddle K, O'Rahilly S, Walker NI \& Cameron DP (1997) Tumor necrosis factor-alpha induces apoptosis of human adipose cells. Diabetes 46, 1939-1944.

Ricquier B (1999) Uncoupling protein-2 (UCP2): molecular and genetic studies. International Journal of Obesity 23, S38S42.

Ristow M, Muller-Wieland D, Pfeiffer A, Krone W, Kahn CR (1998) Obesity associated with a mutation in a genetic regulator of adipocyte differentiation. New England Journal of Medicine 339, 953-959.

Rosenbaum MD, Leibel RL \& Hirsch MD (1997) Obesity. New England Journal of Medicine 337, 396-407.

Rotimi CN, Comuzzie AG, Lowe WL, Luke A, Blangero J \& Cooper RS (1999) The quantitative trait locus on chormosome 2 for serum leptin levels is confirmed in African-Americans. Diabetes 48, 643-276.

Rutherford S, Nyholt DR, Curtain RP, Quinan SR, Gaffney PT, Morris BJ \& Griffiths LR (1997) Association of low density lipoprotein receptor microsatellite variant with obesity. International Journal Obesity 11, 1032-1037.

Schoonjans K, Maring G, Staels B \& Auwerx J (1997) Peroxisome proliferator-activated receptors, orphans with lgiands and function. Current Opinion in Lipidology 8, 159-166.

Schrauwen P, Walder K \& Ravussin E (1999) Human uncoupling proteins and obesity. Obesity Research 7, 97--105.

Sipiläinen R, Uusitupa M, Heikkinen S, Rissanen A \& Laakso M (1997) Polymorphism of the $\beta_{3}$-adrenergic receptor gene affects basal metabolic rate in obese Finns. Diabetes 46, 77-80.

Strobel A, Issad T, Camoin L, Ozata M \& Strosberg AD (1998) Leptin missense mutation association with hypogonadism and morbid obesity. Nature Genetics 18, 213-215.

Strosberg D (1997a) Association of beta ${ }_{3}$-adrenoceptor 
polymorphism with obesity and diabetes: current status. Trends in Pharmacological Sciences 12, 449-454.

Strosberg D (1997b) Structure and function of the beta -adrenergic $_{3}$ receptor. Annual Review of Pharmacology and Toxicolocy 37, 421-450.

Umekawa T, Yoshida T, Sakane N, Kogure A, Kondo M \& Honjyo $H$ (1999) Trp64Arg mutation of $\beta_{3}$-adrenocpetor gene deteriorates lipolysis induced by $\beta_{3}$-adrenoceptor agonist in human omental adipocytes. Diabetes 48, 117-120.

Vaisse C, Clement K, Guy-Grand B \& Frougel P (1998) A framshift mutation in human MC4R is associated with a dominant form of obesity. Nature Genetics 20, 113-114.

Valve R, Heikkinen S, Rissanen A, Laakso M \& Uusitupa M (1998) Synergistic effect of polymorphisms in uncoupling protein 1 and $\beta_{3}$-adrenergic receptor genes on basal metabolic rate in obese Finns. Diabetologia 41, 357-361.
Wacey AL \& Tuddenham EGD (1998) Mutation databases on the web. Journal of Medical Genetics 35, 529-533.

Warden C (1999) Genetics of uncoupling proteins in humans. International Journal of Obesity 23, S46-S48.

Willnow TE (1999) The low-density lipoprotein receptor gene family: multiple roles in lipid metabolism. Journal of Molecular Medicine 77, 306-315.

Wilson AG, Symons JA, McDowell TL, McDevitt HO \& Duff GW (1997) Effects of polymorphism in the human tumor necrosis factor alpha promoter on transcriptional activation. Proceedings of the National Academy of Sciences, USA 7, 3194-3199.

Yeo GSH, Faroogi IS, Aminian S, Halshall DJ, Stanhope RG \& O'Rahilly S (1999) A frameshift mutation in MC4R associated with dominantly inherited human obesity. Nature Genetics $\mathbf{2 0}$, $111-112$. 